\title{
Coatings for Use on Wooden Bicycle Frames - Applicability, Test Methods and Artificial Weathering Results
}

\author{
Premazi za drvene okvire bicikla - \\ primjenjivost, metode ispitivanja i rezultati \\ simuliranog izlaganja vremenskim utjecajima
}

\author{
Original scientific paper • Izvorni znanstveni rad \\ Received - prispjelo: 6. 7. 2016. \\ Accepted - prihvaćeno: 1. 12. 2017. \\ UDK: $630 * 829.2 ; 630 * 835.1$ \\ doi:10.5552/drind.2017.1633
}

\begin{abstract}
Seven different coating systems were tested regarding their suitability for application on bicycle frames made of wood. Since bicycles are ridden throughout the year, the coating system has to withstand different outdoor climate conditions and, especially in winter, the salt brines from the roads. For this reason, an artificial weathering test with an additional freezing step was performed, followed by a specially developed salt brine spray test in ambient outdoor winter climate. Another focus was on the applicability of the coatings. For the tests, a range of coatings, originally developed for wooden front doors, floors and for boat building, was selected. These coatings were expected to meet the main requirements for UV radiation - permanence, weather resistance and saltwater firmness. The main constituents of the coatings were water-based polymer dispersions, two-component polyurethane systems or synthetic and natural oils. The layer thicknesses of the coatings, as well as colour and gloss data of the specimens, were recorded and rated. The adhesion capability was examined by carrying out a cross-cut-test. Surface damages were observed visually. It turned out that colour and gloss change served as good indicators for the decay of the coating. Three different coatings passed the accelerated weathering test. Salt spray had no significant effect on any of the coatings.
\end{abstract}

Keywords: wooden bicycle, wood coating, durability, artificial weathering, salt spray

SAŽETAK • U radu se prikazuju rezultati istraživanja prikladnosti sedam različitih premaznih sustava za drvene okvire bicikla. Budući da se bicikl vozi tijekom cijele godine, premazni sustav mora izdržati različite vremenske utjecaje te, posebice zimi, utjecaj slane vode s cesta. Stoga je provedeno ispitivanje premaza nakon simuliranog izlaganja vremenskim utjecajima s dodatnom fazom zamrzavanja, nakon čega je proveden posebno razvijeni test utjecaja otopine soli na premaz u vanjskim zimskim uvjetima. Drugi fokus bio je na načinu nanošenja premaza. Za istraživanje je odabran niz premaza, izvorno razvijenih za ulazna drvena vrata, podove i brodogradnju, za koje se pretpostavilo da će udovoljiti glavnim zahtjevima za UV zračenje - da će biti trajni, otporni na vremenske uvjete i

\footnotetext{
${ }^{1}$ Authors are professor or researcher at Eberswalde University for Sustainable Development - University of Applied Sciences, Faculty of Wood Science and Technology, Eberswalde, Germany.

${ }^{1}$ Autori su profesori Sveučilišta za održivi razvoj u Eberswaldeu, Sveučilište primijenjenih znanosti, Fakultet za znanost i tehnologiju drva, Eberswalde, Njemačka.
} 
otporni na utjecaj slane vode. Glavni sastojci premaza bile su polimerne disperzije na bazi vode, dvokomponentni poliuretanski sustavi ili sintetička i prirodna ulja. Zabilježena je i ocijenjena debljina sloja premaza te podaci o boji i sjaju uzoraka. Adhezivnost je ispitana metodom zarezivanja mrežice na premazu. Oštećenja površine vizualno su opažana. Pokazalo se da promjena boje i sjaja može poslužiti kao dobar pokazatelj propadanja premaza. Tri različita premaza prošla su ispitivanje ubrzanog izlaganja vremenskim utjecajima. Slani sprej nije imao znatniji učinak ni na jedan od premaza.

Ključne riječi: drveni okvir bicikla, premaz za drvo, izdržljivost, simulirano izlaganje vremenskim utjecajima, slani sprej

\section{INTRODUCTION}

\section{UVOD}

Since the beginning of mobility, wheeled vehicles as well as ships and planes were manufactured from wood (Childe, 1951; Piggott, 1969). For vessels, the protection of wood against UV exposure and salt water has been an issue (Laidlaw, 1952). Even today car manufacturers, as the Morgan Motor Company, use ash wood for their car frames. However, the hygroscopicity and limited durability of wood causes difficulties if used outdoors. At Morgan, therefore, steel or aluminium coverings are used to protect the wooden frame against decay ("The Morgan Motor Company," n.d.). This procedure of wood protection, however, does not make sense on wooden bicycles as weight is an issue and the frame should be visible as a design element (Figure 1). Another way to protect wood is practiced by boat building companies: wooden boats are coated in order to protect them against influences of UV radiation and salt water.

As coatings for wooden bicycle frames also have to provide protection against moisture accumulation in order to prevent biological deterioration, against UVradiation and against deterioration caused by salt brineinduced corrosion, the need has become obvious to apply the wood protection method used in boat building to the bicycle frame building. Furthermore, coatings for wooden bicycle frames have to be flexible but also to show decent bonding properties in order to allow movements of the frame. Baur et al. (2006) studied the weathering performance of different wood species by determining the timber-specific colour degradation. They suggested coating the specimen with clear coat and specific additives in order to strengthen the protection against sunlight degradation. Dawson et al. (2008)

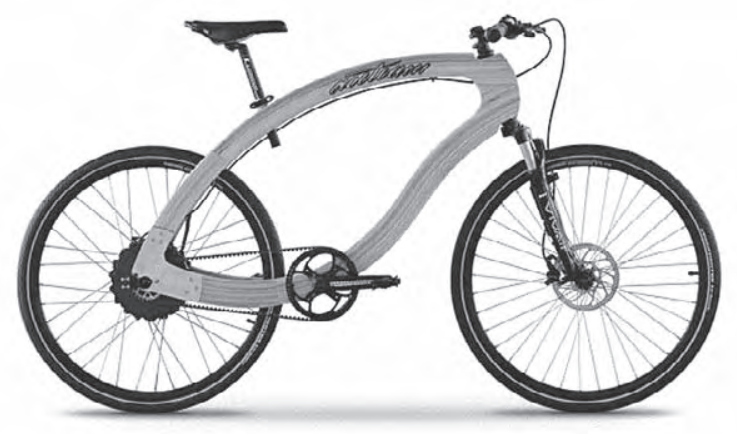

Figure 1 Electrically powered wooden frame bicycle Slika 1. Električni bicikl drvenog okvira proposed to enhance the exterior performance of clear coatings through delignifying the surface cells of Pinus radiata.

Finally, the coating should be easy to apply and maintain. Consequently, coatings were chosen for the bicycle wood frame that met the described requirements. Beside the resistance to weathering of the cured coating, the applicability and maintenance of the coating was also important for its choice.

To prove the performance of coatings on wood, the testing method EN 927-6 (DIN EN 927-6, 2006), which describes the exposure of wood coating systems to artificial weathering using fluorescent UV lights and moisture, was chosen. This method is described as suitable to test the performance of coatings on wood and gives evidence of durability in natural weathering (Grüll et al., 2014).

The main goal of the present study was to find the best UV, weather and salt brine resistant and easiest to maintain coating for wooden frame bicycles.

\section{MATERIALS AND METHODS}

\section{MATERIJALI I METODE}

\subsection{Material}

2.1. Materijal

European ash wood (Fraxinus excelsior L.) lamellae were bound with polyurethane resin and pressed in moulds for the bicycle frame (Figure 2). Specimen with the dimension of $150 \times 75 \times 6 \mathrm{~mm}^{3}$ were prepared from the lamellae and then coated. As there are no coatings available, exclusively developed for wooden bicycle frames, alternative coatings, developed for similar purposes, were investigated.

Besides coatings for front doors, which are directly exposed to weathering, coatings for wooden

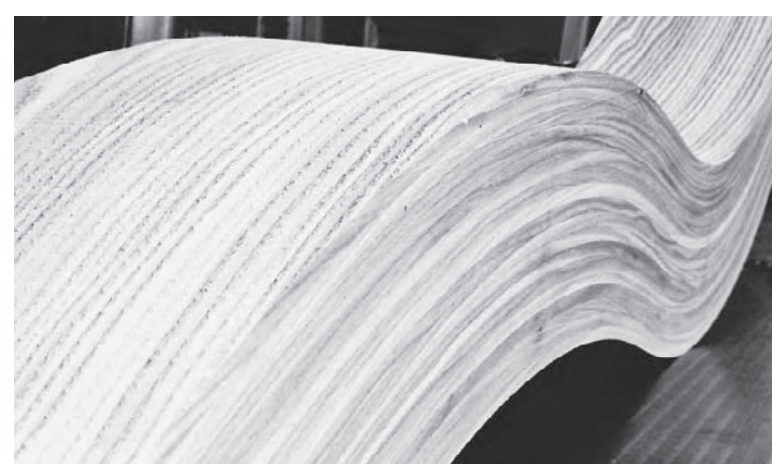

Figure 2 Wooden frame made of ash lamellae Slika 2. Drveni okvir napravljen od jasenova lameliranog drva 
Table 1 Selected coatings

Tablica 1. Odabrani premazi za drvo

\begin{tabular}{|c|c|c|c|c|c|}
\hline $\begin{array}{l}\text { Abbrev. } \\
\text { Kratica }\end{array}$ & $\begin{array}{l}\text { Coating system / type } \\
\text { Premazni sustav / vrsta }\end{array}$ & $\begin{array}{l}\text { Area of applica- } \\
\text { tion } \\
\text { Područje primjene }\end{array}$ & $\begin{array}{c}\text { Intended for } \\
\text { indirect expo- } \\
\text { sure to weather } \\
\text { Namijenjen za } \\
\text { neizravno } \\
\text { izlaganje } \\
\text { vremenskim } \\
\text { utjecajima }\end{array}$ & $\begin{array}{c}\text { Intended for } \\
\text { direct exposure } \\
\text { to weather } \\
\text { Namijenjen za } \\
\text { izravno } \\
\text { izlaganje } \\
\text { vremenskim } \\
\text { utjecajima } \\
\end{array}$ & $\begin{array}{c}\text { Intended } \\
\text { for } \\
\text { seawater } \\
\text { contact } \\
\text { Namijenjen } \\
\text { za kontakt } \\
\text { sa slanom } \\
\text { vodom } \\
\end{array}$ \\
\hline WD & $\begin{array}{l}\text { Water-based polymer dispersion } \\
\text { polimerna disperzija na bazi vode }\end{array}$ & $\begin{array}{l}\text { Exterior } \\
\text { doors } \\
\text { vanjska vrata } \\
\end{array}$ & & $\mathrm{x}$ & \\
\hline PU & $\begin{array}{l}\text { Two-component polyurethane system } \\
\text { dvokomponentni poliuretanski sustav }\end{array}$ & $\begin{array}{l}\text { Furniture and boat } \\
\text { interior } \\
\text { namještaj i interijer } \\
\text { broda }\end{array}$ & $\mathrm{x}$ & & \\
\hline HW & $\begin{array}{l}\text { Hard wax oil } \\
\text { ulje od voska }\end{array}$ & $\begin{array}{l}\text { Wooden floors } \\
\text { drveni podovi }\end{array}$ & $\mathrm{X}$ & & \\
\hline O1 & $\begin{array}{l}\text { Linseed and tung oil } \\
\text { laneno i tung ulje }\end{array}$ & $\begin{array}{l}\text { boat building } \\
\text { brodogradnja }\end{array}$ & & & $\mathrm{x}$ \\
\hline $\mathrm{O} 2$ & $\begin{array}{l}\text { Oil based on alkyd / wood oil / phenolic } \\
\text { resin } \\
\text { ulje na bazi alkida / ulje za drvo / } \\
\text { fenolna smola }\end{array}$ & $\begin{array}{l}\text { boat building } \\
\text { brodogradnja }\end{array}$ & & & $\mathrm{x}$ \\
\hline O3 & $\begin{array}{l}\text { Natural oils, fatty acids and resins } \\
\text { prirodna ulja, masne kiseline } i \text { smole }\end{array}$ & $\begin{array}{l}\text { boat building } \\
\text { brodogradnja }\end{array}$ & & & $\mathrm{x}$ \\
\hline O4 & $\begin{array}{l}\text { Hydrocarbons, alkanes, cyclic and } \\
\text { aromatic compounds, not film building } \\
\text { ugljikovodici, alkani, ciklički i aromat- } \\
\text { ski spojevi; ne stvaraju prevlaku }\end{array}$ & $\begin{array}{l}\text { boat building } \\
\text { brodogradnja }\end{array}$ & & & $\mathrm{x}$ \\
\hline $\mathrm{R}$ & $\begin{array}{l}\text { Reference samples, untreated } \\
\text { referentni uzorci, netretirani }\end{array}$ & & & & \\
\hline
\end{tabular}

flooring and interior coatings, developed to resist abrasion and stain, were selected, as well as coatings for wooden boats, made to withstand weathering and seawater (Table 1).

\subsection{Applicability}

\subsection{Nanošenje premaza}

The coatings consisting of several layers were applied according to the manufacturer instructions. As the repair-friendliness of the coating was in the focus of the manufacturer of the wooden bike, the applicability and maintenance of the coating had to be taken into account as selection criteria. The WD and PU- coating systems could be applied using a low volume low pressure (LVLP) spray gun with $1.4 \mathrm{~mm}$ nozzle - at 150 $\mathrm{kPa}$ air pressure. The WD System consisted of five components: a primer, an intermediate coat and a finish coat, which also needed a hardener and a solvent. The PU system consisted of a filling primer, a hardener and a clear lacquer as finish. All other coatings could be easily applied using a brush, also according to the manufacturer specifications. The oils consisted only of one component. In total, 6 specimen of each coating were produced. Since no matting agents were used, the coatings appear glossy on WD, PU and $\mathrm{O} 1$ specimens and semi-glossy, as defined in EN 927-1 (EN 927-1, 2013), on HW and $\mathrm{O} 3$ after application.

The coatings were applied in a paint booth at ambient room temperature between 18 and $22{ }^{\circ} \mathrm{C}$ and a relative humidity between 40 and $60 \% \mathrm{RH}$. All specimens had to dry for $24 \mathrm{~h}$ in the same conditions between successive coatings. The untreated wood was prepared with 150 grit abrasive paper and sanded with 240 grit abrasive paper between the coatings. The total number of layers for each coating is listed in Table 2.

For comparison, reference samples without coating were produced. The wood lamellae were conditioned in standardized conditions at $20{ }^{\circ} \mathrm{C}$ and $65 \%$ relative humidity for 28 days. Also, coated samples which were not exposed to artificial weathering were produced for the salt spray test and as control samples for the cross cutting test.

For characterization of the several coatings studied herein, the layer thickness of each coating was determined using a microscope at 10x and 20x magnification.

Table 2 Coating: number of layers

Tablica 2. Premaz - broj slojeva

\begin{tabular}{|l|c|c|c|c|c|c|c|}
\hline Sample ID / Oznaka premaza & WD & PU & HW & O1 & O2 & O3 & O4 \\
\hline Number of layers / Broj slojeva & 4 & 3 & 3 & 3 & 3 & 3 & 3 \\
\hline
\end{tabular}


Table 3 Accelerated weathering cycle program

Tablica 3. Ciklički program simuliranog izlaganja vremenskim utjecajima

\begin{tabular}{|c|l|c|c|c|}
\hline Step / Korak & \multicolumn{1}{|c|}{ Function / Funkcija } & Temperature / Temperatura & Duration / Trajanje & Condition / Uvjet \\
\hline 1 & Condensation / kondenzacija & $(45 \pm 3)^{\circ} \mathrm{C}$ & $24 \mathrm{~h}$ & \\
\hline 2 & $\begin{array}{l}\text { Subcycle / podciklus: } \\
\text { 32 cycles of step 3 and } 4 \\
\text { 32 ciklusa koraka 3. } i \text { 4. }\end{array}$ & & $96 \mathrm{~h}$ & \\
\hline 3 & $\begin{array}{l}\text { UV- exposure } \\
\text { izlaganje UV zračenju }\end{array}$ & $(60 \pm 3)^{\circ} \mathrm{C}$ & $2.5 \mathrm{~h}$ & $\begin{array}{c}\text { Irradiance set point } \\
0.89 \mathrm{~W} / \mathrm{m}^{2} \text { at } 340 \mathrm{~nm}\end{array}$ \\
\hline 4 & Spray / raspršivač & & $0.5 \mathrm{~h}$ & $6 \mathrm{l} / \mathrm{min}$ to $7 \mathrm{l} / \mathrm{min}, \mathrm{UV}$ off \\
\hline 5 & Freezing / zamrzavanje & $(-25 \pm 1)^{\circ} \mathrm{C}$ & $48 \mathrm{~h}$ & \\
\hline
\end{tabular}

\subsection{Artificial weathering}

\subsection{Simulirano izlaganje vremenskim utjecajima}

Three days after completing the preparation of the samples, different coatings were tested following the EN 927-6 (DIN EN 927-6, 2006), which describes the exposure of wood coating systems to artificial weathering using fluorescent UV lights and moisture. As weathering tester, a Q-LAB QUV accelerated weathering testing machine was used. The machine simulates the effects of sunlight, dew and rain with UV- exposure, condensing humidity and water spray in alternating cycles.

As cold winter conditions also had to be simulated, a freezing step was inserted into the standard cycle, and the duration of the UV- exposure and spray subcycle was shortened from 48 to 32 (Table 3). For freezing, the samples were alternately removed from UV and from the spraying step at the end of each cycle. The samples were frozen in a laboratory freezer at a controlled temperature of $-25^{\circ} \mathrm{C}$. In order to intensify the climatic stress, 14 cycles were performed instead of 12 .

\subsection{Measurement of colour and gloss changes 2.4. Mjerenje promjene boje i sjaja}

Before each weathering cycle, the coating surface of each specimen was inspected by human eye for colour change, yellowing, fading, cracks and flaking following DIN EN ISO 4628-4 and 5 (DIN EN 4628-4, 2004, DIN EN ISO4628-5, 2004). For an evaluation of colour differences with the naked eye, scales as shown in Table 4 are often used. Additionally, at six individual spots on each specimen, the colour, lightness and gloss data were measured and recorded at the beginning of each weathering cycle with a BYK-Gardner spectroguide 45/0 gloss spectrophotometer. The colour and lightness were determined in the CIE system (Commission Internationale de l'eclairage), according to DIN EN ISO 11664-4 (DIN EN ISO 11664-4, 2012), where the $L^{*} a^{*} b^{*}$ colour space is described as a treedimensional space, where $L^{*}$ stands for lightness, $a^{*}$ is a green to red coordinate and $b^{*}$ is a blue to yellow coordinate.

The $\Delta E_{a b}^{*}$ (Equation 1) indicates the colour and lightness differences of the tested wood coatings and colour change during test procedure.

$$
\Delta E^{*}{ }_{\mathrm{ab}}=\left(\left(L_{2}^{*}{ }_{2}-L_{1}^{*}\right)^{2}+\left(a^{*}{ }_{2}-a^{*}{ }_{1}\right)^{2}+\left(b^{*}{ }_{2}-b^{*}{ }_{1}\right)^{2}\right)^{1 / 2}
$$

The mean values of colour and lightness differences were measured at the beginning of each testing cycle and mapped in a diagram (Figures 5 and 6). The intensity of the reflected light was measured as Gloss units (GU) together with colour and lightness at the beginning of each cycle.

\subsection{Cross cutting test}

2.5. Određivanje adhezije premaza metodom zarezivanja mrežice

DIN EN 927-6 requires a cross-cut test for the evaluation of adhesion capability of varnish on wooden surface. Two weeks after having passed the accelerated weathering cycle, a right angle lattice pattern was manually cut into the coating with a blade according to EN ISO 2409 (ISO 2409, 2013).

An average distance of $2 \mathrm{~mm}$ from each cutting line is required for soft substrates and layer thicknesses up to $60 \mu \mathrm{m}$. After cutting, the adhesion resistance of coatings to separation from the wood surface is tested using an adhesion tape applied over the grid. Five minutes after application, the tape is removed at an angle of $60^{\circ}$. The test results were classified according to EN ISO 2409 from 0 (no visible changes) to 5 (the worst adhesion), As only the WD, $\mathrm{O} 1$ and $\mathrm{O} 2$ series samples withstood the weathering cycle with an unscathed surface, these were rated and the mean value of each sample series was calculated. For comparison purposes, unexposed samples were also subjected to the cross-cut test.

Table 4 Rating scale for colour differences (Buchelt and Pfriem, 2010)

Tablica 4. Ljestvica ocjena promjene boje (Buchelt and Pfriem, 2010.)

\begin{tabular}{|c|l|}
\hline$\Delta \boldsymbol{E}$ & \multicolumn{1}{c|}{ Rating / Ocjena } \\
\hline $0.0 \ldots 0.5$ & no difference or almost no difference / uopće nema ili gotovo nema razlike u boji \\
\hline $0.5 \ldots 1.0$ & difference may be noticeable to the trained eye / promjena je primjetna samo obučenom promatraču \\
\hline $1.0 \ldots 2.0$ & imperceptible colour difference / neprimjetna razlika u boji \\
\hline $2.0 \ldots 4.0$ & perceived colour difference / percipirana razlika u boji \\
\hline $4.0 \ldots 5.0$ & significant difference in colour, which is rarely tolerated / znatna razlika boje koja se rijetko tolerira \\
\hline above 5.0 & the difference is judged to be other colour / razlika boje je takva da se procjenjuje kao druga boja \\
\hline
\end{tabular}


For a more detailed evaluation, the samples were classified using a microscope with 10x and 20x magnification.

\subsection{Salt-spray- test}

\subsection{Test raspršivanja slane otopine}

To test the suitability of the bike frame coating for use in winter, two months after the accelerated weathering cycles, a salt-spray- test was performed in addition to the weathering test. Most corrosion tests for (coated) metal are based on a salt spray test, in which metal sample coupons are exposed to the salt spray. Such test methods are described in international standards such as ASTM B117 „Standard Practice for Operating Salt Spray (Fog) Apparatus“ (ASTM B117, 2011), ISO 9227 (ISO 9227, 2012) „Corrosion Tests in Artificial Atmospheres - Salt Spray Tests“ or EN 60068-2-11 „Basic Environmental Testing Procedures, Part 2: Test KA: Salt Mist“ (DIN EN 60068-2-11, 2000) and EN 60068-2-52 „Environmental Testing Part 2: Test. Test KB. Salt Mist, Cyclic (Sodium Chloride Solution)" (EN 60068-2-52, 1996).

In standards for the automotive industry other test methods are also described, in which the parts are not exposed to a continuous salt spray, but are directly sprayed with salt brine. An example for this is the GMW 14872 Cyclic Corrosion Laboratory Test procedure (GMW14872, 2006), which provides an accelerated corrosion test for parts and components under laboratory conditions. The test method provides a combination of cyclic load by moisture, drying and salt spray to accelerate corrosion. The DIN EN ISO 15710 (2006) is intended primarily to test the protective effect of coatings on aluminium and aluminium alloys against corrosion and is vastly used in the aerospace industry. In this test method, a coated sample plate, whose coating is scratched, is alternately immersed in a dilute salt solution and removed from it.

Various testing methods indicate that there are different approaches to examine the influence of corrosion on materials and surface coatings. For the present

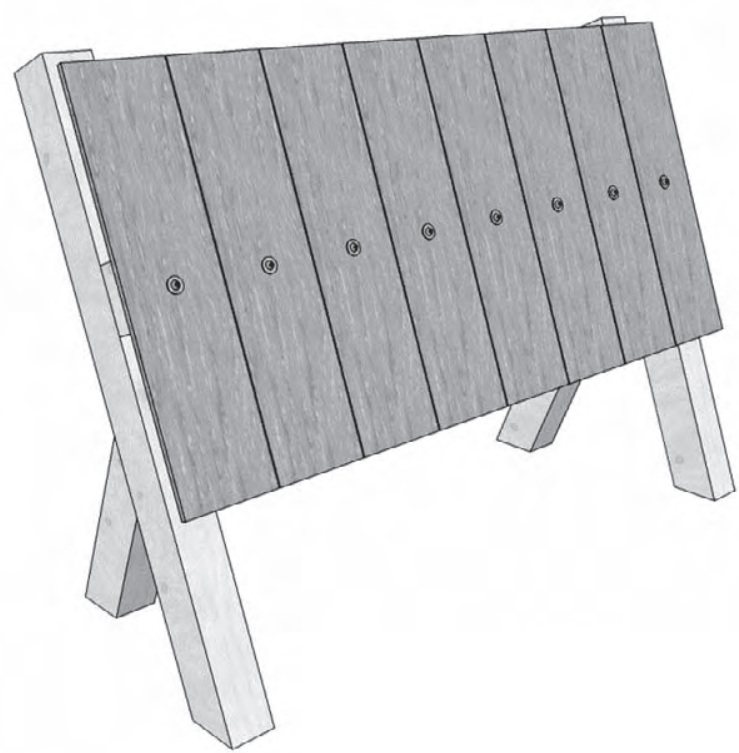

Figure 3 Rig for the salt spray test with mounted specimens Slika 3. Sustav za ispitivanje utjecaja raspršene slane otopine na drvne premaze

application, the resistance of a wooden bicycle frame against pre-wetted salt, used by winter services in Germany, was of particular interest. Based on test methods for metallic components, a test method was developed to examine direct contact of coated wood with salt and brine. The specimens with a size of $75 \mathrm{~mm}$ x $300 \mathrm{~mm}$ were mounted on a frame in a $20^{\circ}$ inclination (Figure 3 ) in southern direction and exposed to a natural outdoor climate for eight weeks. Temperature and relative humidity were continuously recorded (Figure 4).

German winter services mostly use up to $40 \mathrm{~g} / \mathrm{m}^{2}$ of the so-called wet salts to defrost snow or ice covered roads. Wet salts consist of dry salts moistened with saline. Accordingly, saturated brine, consisting of $22 \%$ sodium chloride and $78 \%$ water was prepared. Through a period of 8 weeks $60 \mathrm{~g} / \mathrm{m}^{2}$ of the salt solution was sprayed on the samples twice a day.

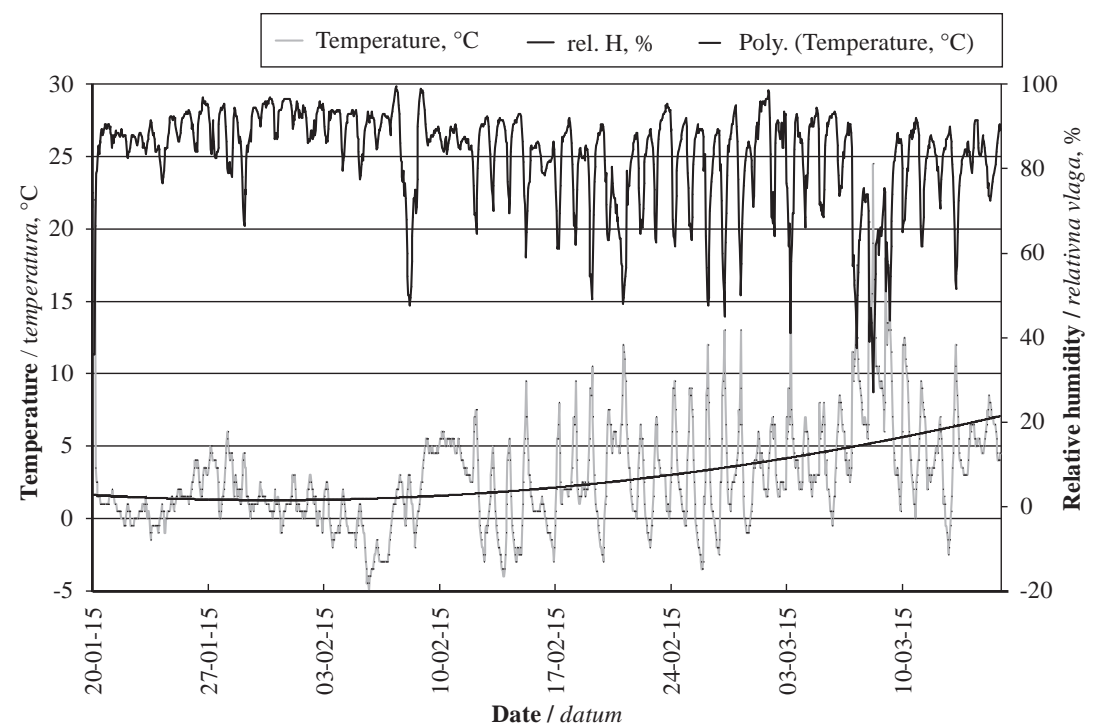

Figure 4 Recorded temperature and relative humidity, polynomic regression of temperature during salt spray test Slika 4. Registrirana temperatura i relativna vlažnost zraka, polinomska regresija temperature tijekom ispitivanja raspršivanjem slane otopine 


\section{RESULTS AND DISCUSSION}

\section{REZULTATI I RASPRAVA}

\subsection{Applicability}

3.1. Nanošenje premaza

It can be noted that, regardless of the method of application, layer thicknesses ranging between 35 and $50 \mu \mathrm{m}$ were obtained (Table 5). With an average layer thickness of $18.0 \mu \mathrm{m}$, the $\mathrm{O} 4$ product had the lowest layer thickness - due to the fluidity and method of application (wood had to be «saturated» with the oil at least one day) - Furthermore, the thickest layer of 51.8 $\mu \mathrm{m}$ was measured for the $\mathrm{O} 1$ product.

Both methods of application have advantages and disadvantages over the other method. The coating applied using a spraying gun produces a thinner and more uniform film. If repairs are necessary, preference must be given to the oils, because of the simpler application. Repairs of a multi-layered coating system can only be carried out by a qualified workshop.

\subsection{Colour and gloss change}

3.2. Promjena boje i sjaja

Form the beginning of weathering, a colour change and darkening of all specimens could be noticed. As shown in the average $\Delta E^{*}{ }_{\text {ab }}$ change diagram (Figure 5), the colour of all samples changed after the first cycle. All coated samples showed the tendency to become darker (Figure 6) at as long as the surfaces were not damaged. A washout of the coating generally leads to flaking and, therefore, to a loss of protection against bleaching by UV irradiation. After the end of the fourth cycle, colour changes on PU and $\mathrm{O} 4$ samples could be measured. Only one week later, the discolouration could be seen by the naked eye.
The beginning of bleaching of the coating of HW samples could be measured after the fifth week by $\Delta E^{*}$ data acquisition. On $\mathrm{O} 3$ samples, a visible fading could first be detected four weeks later. As the coating was largely destroyed having passed the eleventh cycle, the PU (quantity five, crack width parameter 3 according to DIN EN ISO 4628-4), O4 and HW (severe fading) coatings were removed from the artificial weathering cycle.

For all other samples, up to the $13^{\text {th }}$ cycle, no flaking was detected. However, after the last cycle, incipient fading was observed also with the naked eye on the O3- samples.

The coated specimens became glossier after the first cycle. During the following test cycles, the gloss decreased in all samples. At the end of the tenth cycle, a significantly stronger decreasing of gloss of the $\mathrm{O} 1$, $\mathrm{O} 2$ and PU samples was detected (Figure 7).

\subsection{Cross Cutting Test}

3.3. Određivanje adhezije premaza metodom zarezivanja mrežice

For comparison, specimens of all coated but not weathered control samples were cross cut. It can be stated that all control samples had intact surfaces, so all of these samples could be categorized as „0“ according to DIN EN ISO 2409. A cross cut of an intact HW surface with classification " 0 " is shown in Figure 8. From the samples exposed to weathering, only the samples that withstood the 14 cycles weathering test with an obviously intact surface were tested by cross-cut. The cross-cut samples of $\mathrm{O} 1$ and $\mathrm{O} 2$ series could be classified as 0-1 (Figure 9) after weathering. In case of the WD series, a cross-cut area between $5 \%$ and $15 \%$ showed flaking (Figure 10) (Table 6).

Table 5 Average layer thicknesses of the coating $(\mu \mathrm{m})$ and standard deviation

Tablica 5. Prosječna debljina sloja premaza $(\mu \mathrm{m})$ i standardna devijacija

\begin{tabular}{|l|c|c|c|c|c|c|c|}
\hline Sample ID / Oznaka premaza & WD & PU & HW & O1 & O2 & O3 & O4 \\
\hline Average layer thickness, $\mu \mathrm{m}$ & 48.1 & 34.8 & 38.6 & 51.8 & 40.6 & 35.4 & 18.0 \\
Prosječna debljina sloja, $\mu \mathrm{m}$ & $\mathbf{( 5 . 8 2 )}$ & $(2.15)$ & $(7.23)$ & $(7.19)$ & $(5.00)$ & $(4.55)$ & $(4.67)$ \\
\hline
\end{tabular}

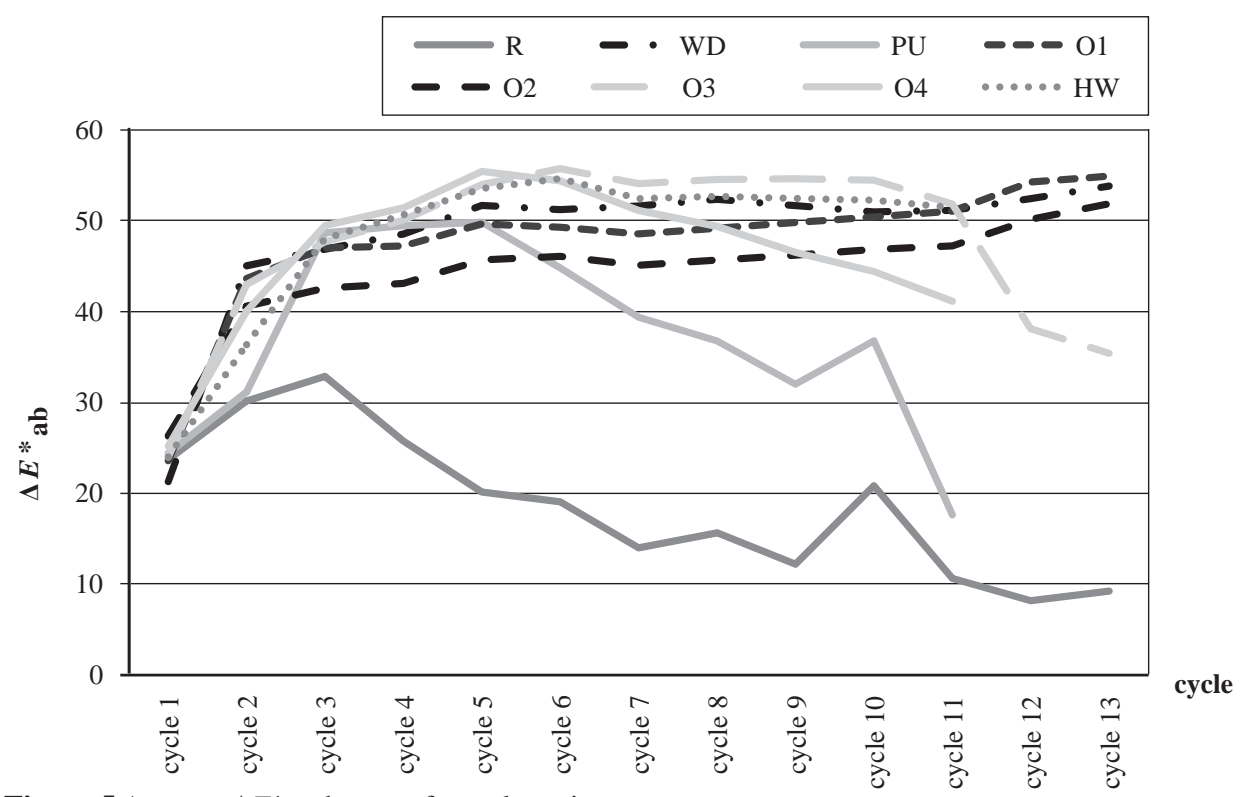

Figure 5 Average $\Delta E^{*}$ change of wood coatings

Slika 5. Prosječna promjena boje $\Delta E^{*}{ }_{\text {ab }}$ drvnog premaza 


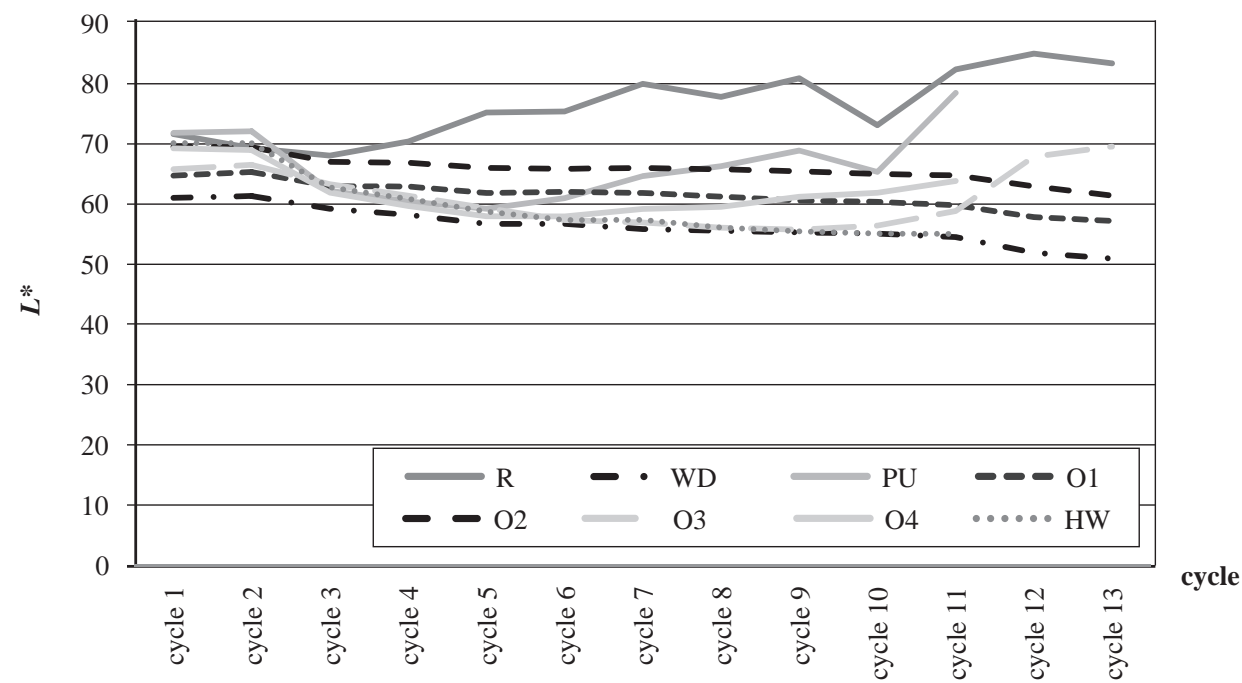

Figure 6 Average $L^{*}$ change of wood coatings

Slika 6. Prosječna promjena svjetline $L^{*}$ drvnog premaza

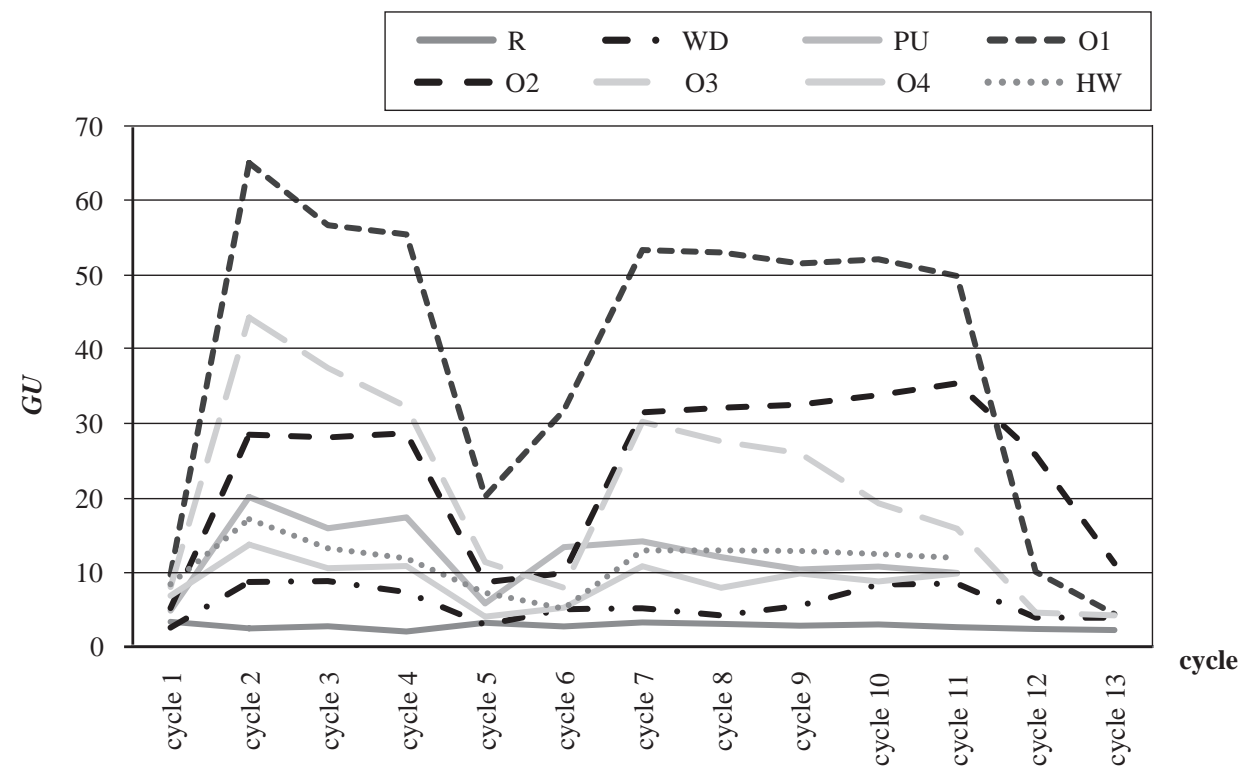

Figure 7 Average gloss unit change of wood coatings

Slika 7. Prosječna promjena sjaja drvnog premaza

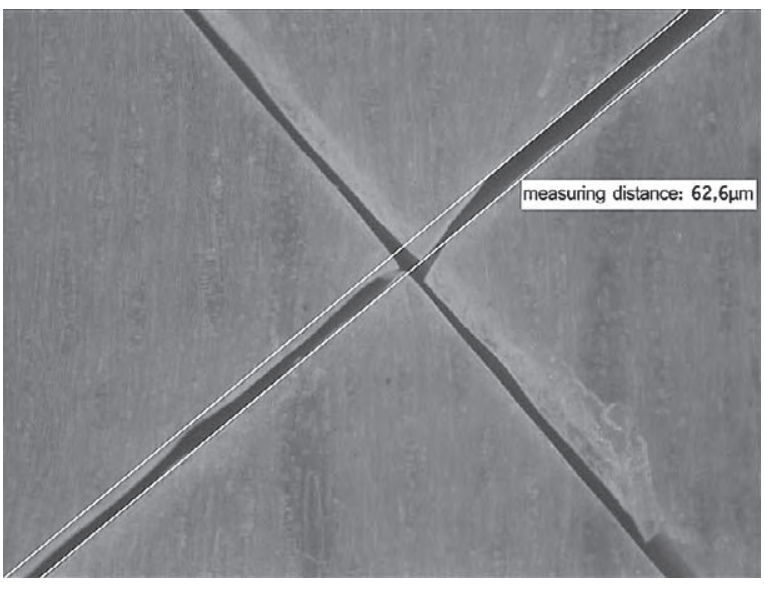

Figure 8 Microscopic image (10x magnification) of a cross-cut of an HW sample with intact coating on its surface. The edges of the cut are smooth and without detachments. $0 \%$ of the cut area is affected by flaking Slika 8. Mikroskopska slika (uvećanje 10 puta) zarezane mrežice HW uzorka s nepropusnim premazom na površini; rubovi rezanja glatki su i bez odvajanja; ljuštenja površine zazrezivanja nije bilo

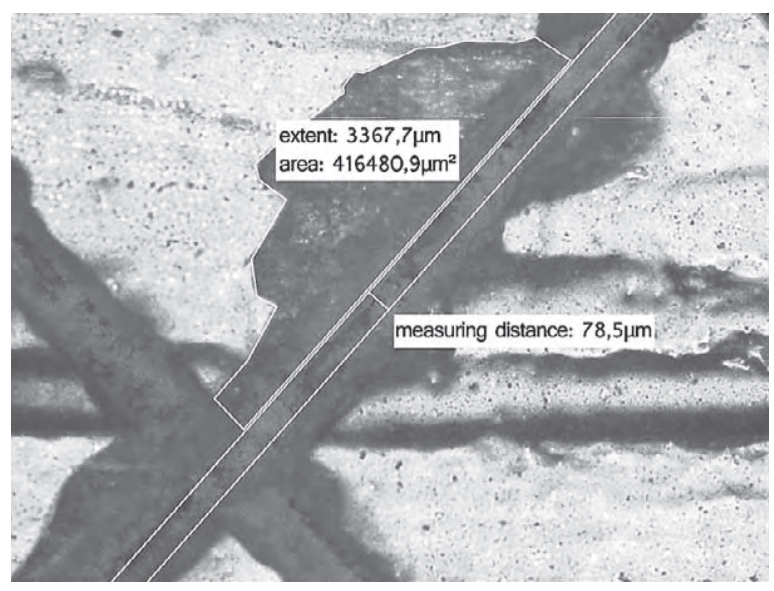

Figure 9 Cross-cut of the weathered $\mathrm{O} 2$ coating, view through microscope at 20x magnification. Maximum $5 \%$ of the cut area shows small flakes of the coating at the intersections of the cuts

Slika 9. Zarezana mrežica premaza $\mathrm{O} 2$ nakon izlaganja vremenskim utjecajima; pogled mikroskopom uz povećanje 20 puta; maksimalno 5 \% površine zarezivanja pokazuje malo ljuštenje premaza na sjecištima rezova 


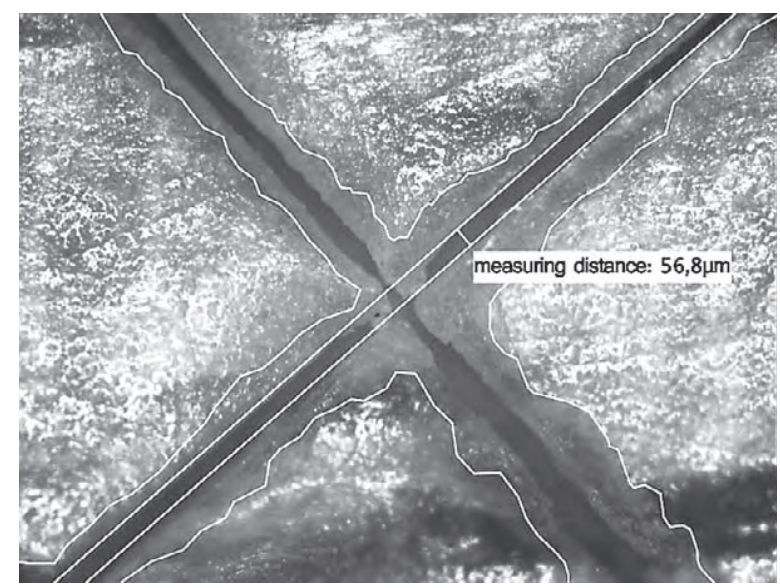

Figure 10 Cross-cut on weathered coating of WD sample, view through microscope at 10x magnification, example for classification 2. The coating has flaked along the edges and at the intersections of the cuts. A cross-cut area greater than $5 \%$ is affected.

Slika 10. Zarezana mrežica premaza WD nakon izlaganja vremenskim utjecajima; pogled mikroskopom pri uvećanju 10 puta; primjer za klasifikaciju 2; premaz je oljušten duž rubova i na križanju rezova; promjene su zabilježene na površini zarezivanja većoj od $5 \%$

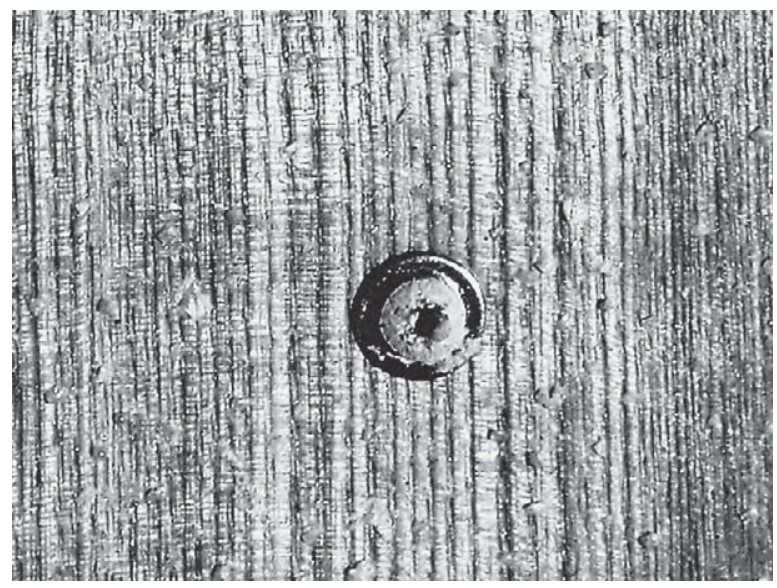

Figure 11 Specimen after eight weeks of salt spray test: corrosion appearances on stainless steel screws and salt crystals on the specimen.

Slika 11. Uzorak nakon osam tjedana testiranja slanom otopinom; pojava korozije na vijcima od nehrđajućeg čelika i kristali soli na uzorku

Table 6 Results of cross-cut test for samples after 14 cycles weathering test

Tablica 6. Rezultati ispitivanja adhezije premaza metodom zarezivanja mrežice nakon 14 ciklusa izlaganja vremenskih utjecajima

\begin{tabular}{|c|c|c|c|}
\hline Sample series / Serija uzoraka & WD series / Serija WD & O1 series /Serija O1 & O2 series / Serija O2 \\
\hline $\begin{array}{c}\text { Average classification } \\
\text { Prosječna klasifikacija }\end{array}$ & $1-2$ & $0-1$ & $0-1$ \\
\hline
\end{tabular}

\subsection{Salt-spray- test}

3.4. Test raspršivanja slane otopine

The self-developed salt-spray-test follows the conditions that prevail on wintry German roads, and no generally valid conclusions can be drawn on its basis. For this purpose, a standardized test would have to be developed, that would also take into consideration colour and gloss measurements. This salt-spray test showed that, at the end of twelve weeks in ambient moderate winter climate, all test specimens survived the test unscathed. In periods of rising temperatures, the brine formed salt crystals on the surface of the specimen. These could be easily washed off. The surfaces had no visible cracks or flaking; neither the crystals nor the brine itself had an effect on the varnish. Corrosion appeared only on the stainless steel screw fasteners and washers (Figure 11). Table 5 shows the results of the single tests in a brief summary.

\section{CONCLUSIONS \\ 4. ZAKLJUČAK}

Although recommended, the two-component PU coating system is not suitable for the intended use, as

Table 7 Summary table of final results

Tablica 7. Tablica konačnih rezultata

\begin{tabular}{|c|c|c|c|c|}
\hline $\begin{array}{c}\text { Sample ID } \\
\text { Oznaka } \\
\text { premaza }\end{array}$ & $\begin{array}{c}\text { Applicability } \\
\text { Nanošenje premaza }\end{array}$ & $\begin{array}{c}\text { Colour and gloss change } \\
\text { Promjena boje } \text { i sjaja }\end{array}$ & $\begin{array}{c}\text { Cross Cutting Test } \\
\text { Test zarezivanja mrežice }\end{array}$ & $\begin{array}{c}\text { Salt Spray Test } \\
\text { Test slanim sprejom }\end{array}$ \\
\hline $\mathrm{WD}$ & $\begin{array}{c}\text { Spray gun necessary } \\
\text { obvezno štrcanjem }\end{array}$ & passed / prošao & $1-2$ & passed / prošao \\
\hline $\mathrm{PU}$ & $\begin{array}{c}\text { Spray gun necessary } \\
\text { obvezno štrcanjem }\end{array}$ & failed / nije prošao & $\begin{array}{c}\text { No analysis possible } \\
\text { nije moguća analiza }\end{array}$ & passed / prošao \\
\hline $\mathrm{HW}$ & manually / ručno & failed / nije prošao & $\begin{array}{c}\text { No analysis possible } \\
\text { nije moguća analiza }\end{array}$ & passed / prošao \\
\hline $\mathrm{O} 1$ & manually / ručno & passed / prošao & $0-1$ & passed / prošao \\
\hline $\mathrm{O} 2$ & manually / ručno & passed / prošao & passed / prošao \\
\hline $\mathrm{O} 3$ & manually / ručno & failed / nije prošao & $\begin{array}{c}\text { No analysis possible } \\
\text { nije moguća analiza }\end{array}$ & passed / prošao \\
\hline $\mathrm{O} 4$ & manually / ručno & failed / nije prošao & $\begin{array}{c}\text { No analysis possible } \\
\text { nije moguća analiza }\end{array}$ & passed / prošao \\
\hline
\end{tabular}


only after finishing the fifth cycle, flaking of the coating could be noticed. The hard wax oil, which is intended for the use on wooden floors, bleached at the beginning of the $8^{\text {th }}$ week. Also, two boat building oils failed. Flaking appeared on the $\mathrm{O} 4$ specimen after only six cycles, due to leaching. The $\mathrm{O} 3$ oil faded at the end of the weathering cycle. The multi-component waterbased coating for exterior doors (WD) and two oilbased coatings from manufacturers of yacht coatings (O1 and O2) can be recommended for the year round use as a good protection for wooden bicycle frames.

Considering the results of the colour change and gloss measurements, it can be concluded that the tested coatings, exposed to accelerated weathering, have shown significant differences in resistance to UV radiation and extreme climate conditions. It turned out that the measurement of colour changes in artificial weathering tests is - together with the cross cut test - an effective way to determine suitable coating products for wooden frames. The salt brine spray test showed no further degradation on the coating surface.

Taking into account the results from the colour and gloss measurements, the use of a multi-component water based coating, as well as some of the oil based paints for boat building, can be recommended for the intended application.

In order to create a stress scenario on wooden bikes that is closer to a real daily use, in future tests, the coated wooden lamellae could be exposed to mechanical forces before weathering. Additionally, the resistance of coatings against crushed stones from the road surface and their ability to withstand abrasion in daily use could be part of future testing.

\section{Acknowledgements - Zahvala}

The authors gratefully acknowledge the financial support of the Federal Ministry for Economic Affairs and Energy (Grant No. KF 2122215LL3) and the cooperation with our project partner, System 180. In addition, we wish to thank the city of Eberswalde Building Yard and Road Maintenance Department for providing sodium chloride for the experiments.

\section{REFERENCES}

\section{LITERATURA}

1. Baur, S.; Easteal, A.; Edmonds, N.; Waddingham, D.; Jones, R.; Devendra, R., 2006: Photoprotection and photostabilisation of timber surfaces using clear coatings. Surf. Coat. Aust. 43, 20.

2. Buchelt, B.; Pfriem, A., 2010: Thermisch modifizierte Furniere für dekorative Zwecke. 6th Europäischer TMTWorkshop, Dresden, Germany.

3. Childe, V. G., 1951: The First Waggons and Carts - from the Tigris to the Severn. Proc. Prehist. Soc. New Ser. 17: 177-194. http://dx.doi.org/10.1017/S0079497X00018673.

4. Dawson, B. S.; Singh, A. P.; Kroese, H. W.; Schwitzer, M. A.; Gallagher, S.; Riddiough, S. J.; Wu, S., 2008: Enhancing exterior performance of clear coatings through photostabilization of wood. Part 2: coating and weather- ing performance. J. Coat. Technol. Res. 5: 207-219. http://dx.doi.org/10.1007/s11998-008-9089-5.

5. Grüll, G.; Tscherne, F.; Spitaler, I.; Forsthuber, B., 2014: Comparison of wood coating durability in natural weathering and artificial weathering using fluorescent UVlamps and water. Eur. J. Wood Wood Prod. 72: 367-376. http://dx.doi.org/10.1007/s00107-014-0791-y.

6. Laidlaw, F. B., 1952: Marine fouling and its prevention. United States Naval Institute, Annapolis, Maryland.

7. Piggott, S., 1969: The Earliest Wheeled Vehicles and the Caucasian Evidence. Proc. Prehist. Soc. New Ser. 34: 266-318. http://dx.doi.org/10.1017/S0079497X00013918.

8. ***ASTM B117, 2011. ASTM B117-11 Practice for Operating Salt Spray (Fog) Apparatus.

9. *** EN 927-1, 2013. EN 927-1:2013-05 Paints and varnishes - Coating materials and coating systems for exterior wood - Part 1: Classification and selection

10. ***DIN EN 927-6, 2006. DIN EN 927-6:2006-10 Paints and varnishes - Coating materials and coating systems for exterior wood - Part 6: Exposure of wood coatings to artificial weathering using fluorescent UV lamps and water

11. ***DIN EN 60068-2-11, 2000. DIN EN 60068-211:2000-02 - Environmental testing - Part 2: Tests; test KA: Salt mist.

12. ***DIN EN ISO 15710, 2006. DIN EN ISO 15710:200609 - Paints and varnishes - Corrosion testing by alternate immersion in and removal from a buffered sodium chloride solution.

13. ***EN 60068-2-52, 1996. EN 60068-2-52:1996-10 Environmental testing - Part 2: Tests, Test KB: Salt mist, cyclic (sodium chloride solution).

14. ***GMW14872, 2006. GMW14872 - Cyclic Corrosion Laboratory Test.

15. ***ISO 2409, 2013. ISO 2409:2013-02 - Paints and varnishes - Cross-cut test.

16. ${ }^{* * *}$ DIN EN ISO 4628-4, 2004. DIN EN ISO 4628-4: 2004-01 - Paints and varnishes - Evaluation of degradation of coatings - Designation of quantity and size of defects, and of intensity of uniform changes in appearance - Part 4: Assessment of degree of cracking.

17. ***DIN EN ISO 4628-5, 2004. DIN EN ISO 4628-5: 2004-01 - Paints and varnishes - Evaluation of degradation of coatings - Designation of quantity and size of defects, and of intensity of uniform changes in appearance - Part 5: Assessment of degree of flaking

18. ***DIN EN ISO 11664-4, 2012. DIN EN ISO 116644:2012 - 06 - Colorimetry - Part 4: CIE 1976 L*a*b* Colour space.

19. ***ISO 9227, 2012. ISO 9227:2012-09 - Corrosion tests in artificial atmospheres - Salt spray tests.

20. *** http://www.morgan-motor.co.uk/mmc/newspages/ ash.html (accessed 31. 5. 2016).

\section{Corresponding address:}

\section{Prof. Dr.-Ing. ALEXANDER PFRIEM}

Eberswalde University for Sustainable Development

Faculty of Wood Engineering

Schicklerstraße 5

16225 Eberswalde, GERMANY

e-mail: Alexander.Pfriem@hnee.de 